\title{
Inhibitory Effect of Methanol Extract of Ganoderma lucidum on Acute Itch-Associated Responses in Mice
}

\author{
Qun Zhang, ${ }^{a}$ Tsugunobu Andoh, ${ }^{a}$ Mitsuhiro Konno, ${ }^{a}$ Jung-Bum Lee, ${ }^{b}$ Masao Hattori, ${ }^{c}$ and \\ Yasushi KuRAISHI ${ }^{*, a}$ \\ ${ }^{a}$ Department of Applied Pharmacology, University of Toyama; ${ }^{b}$ Department of Pharmacognosy, Graduate School of \\ Medicine and Pharmaceutical Sciences, University of Toyama; and ${ }^{c}$ Division of Metabolic Engineering, Institute of \\ Natural Medicine, University of Toyama; 2630 Sugitani, Toyama 930-0914, Japan. \\ Received January 11, 2010; accepted February 19, 2010; published online February 23, 2010
}

In this study, the antipruritic effect of the methanol extract of Ganoderma lucidum (MEGL) was studied in mice. Oral administration of MEGL $(10-1000 \mathrm{mg} / \mathrm{kg})$ produced a dose-dependent inhibition of scratching, an itch-related response, induced by intradermal 5-hydroxytryptamine $(5-\mathrm{HT})(100 \mathrm{nmol} / \mathrm{site}), \alpha$-methyl-5-HT $(100 \mathrm{nmol} / \mathrm{site})$, and proteinase-activated receptor-2 $\left(\mathrm{PAR}_{2}\right)$-activating peptide SLIGRL- $\mathrm{NH}_{2}(50 \mathrm{nmol} / \mathrm{site})$. However, MEGL $(100-1000 \mathrm{mg} / \mathrm{kg})$ did not inhibit the scratching induced by histamine $(100 \mathrm{nmol} / \mathrm{site})$, substance $P$ $(100 \mathrm{nmol} / \mathrm{site})$, and compound $48 / 80(10 \mu \mathrm{g} / \mathrm{site})$. These results raise the possibility that MEGL is effective against pruritus mediated by proteinases and 5-HT and that primary afferents expressing $\mathrm{PAR}_{2}$ and $5-\mathrm{HT}_{2 \mathrm{~A}}$ receptors are the sites of its action.

Key words Ganoderma lucidum; itch; proteinase-activated receptor; serotonin; scratch

Itch, a skin sensation that provokes the desire to scratch, accompanies various skin diseases such as atopic dermatitis. Although $\mathrm{H}_{1}$ histamine-receptor antagonists are the drugs of first choice for the treatment of itch, many pruritic diseases except acute urticaria do not show a good response. ${ }^{1)}$ Therefore, it is important to develop new drugs that are effective against antihistamine-resistant pruritus.

The fruiting body of Ganoderma lucidum (G. lucidum) KARST has been used as a crude drug in China, Japan, and Korea for the treatment of hypertension, chronic hepatitis, hyperglycemia, cancer, and chronic bronchitis. ${ }^{2,3)}$ The extract of G. lucidum has been shown to have an antiallergic activity, which is mainly due to its inhibitory effect on the histamine release from mast cells. ${ }^{4,5)}$ Many antiallergic drugs generally show antipruritic activity, ${ }^{6}$ but the antipruritic activity of $G$. lucidum has not yet been elucidated.

Scratching, an itch-related response, can be elicited by intradermal injections of various substances, including histamine, ${ }^{7)}$ substance $\mathrm{P}^{8,9)}$ 5-hydroxytryptamine $(5-\mathrm{HT}){ }^{10)}$ proteinase-activated receptor-2 $\left(\mathrm{PAR}_{2}\right)$-activating peptide, ${ }^{11)}$ and compound $48 / 80 .{ }^{8,12}$ Scratching induced by these substances may not be mediated by the same primary afferents., ${ }^{9,13-15}$ ) Therefore, in the present study, we examined whether $G$. lucidum can ameliorate the scratching elicited by the pruritogens mentioned above in order to determine the antipruritic efficacy of G. lucidum and its possible mechanisms.

\section{MATERIALS AND METHODS}

Animals Male ICR mice (Japan SLC, Ltd., Shizuoka, Japan) aged 5-8 weeks and weighing $24-26 \mathrm{~g}$ were used. They were housed under controlled temperature $\left(23^{\circ} \mathrm{C} \pm\right.$ $1{ }^{\circ} \mathrm{C}$ ), humidity $(60 \% \pm 5 \%$ ), and light (lights on from 8:00 $20: 00 \mathrm{~h}$ ). Food and water were freely available. Procedures for animal experiments were approved by the Committee for Animal Experiments at the University of Toyama and were conducted in accordance with the guidelines of the Japanese Pharmacological Society.

Agents 5-HT, $\alpha$-methyl-5-HT, and compound 48/80 were purchased from Sigma (St. Louis, MO, U.S.A.). Substance $\mathrm{P}$ and histamine were purchased from Peptide Institute, Inc. (Osaka, Japan) and Wako Pure Chemical Industries, Ltd. (Osaka, Japan), respectively. Ser-Leu-Ile-Gly-Arg-Leu$\mathrm{NH}_{2}$ (SLIGRL- $\mathrm{NH}_{2}$ ) was synthesized and identified by JBL with a peptide synthesizer PSSM-8 (Shimadzu Co., Kyoto, Japan) and a matrix assisted laser desorption/ionization timeof-flight (MALDI TOF)-MS Autoflex T1 (Bruker Daltonics, Billerica, MA, U.S.A.), respectively. These agents were dissolved in physiological saline and injected intradermally in a volume of $50 \mu \mathrm{l}$ into the rostral skin of mice, the hair of which was clipped a day before the experiment was conducted.

Preparation of the Methanol Extract of G. Iucidum (MEGL) The dried powder (1 kg) of G. lucidum (Koshiro Co., Ltd., Kyoto, Japan) was extracted three times with methanol for $3 \mathrm{~h}$ and the methanol extract was then dried; the yield of MEGL was $17.8 \%$. MEGL was suspended in 5\% gum arabic before use and was administered orally $1 \mathrm{~h}$ before the pruritogen injection.

Behavioral Observation The animals were put into an acrylic cage containing four cells $(13 \times 9 \times 40 \mathrm{~cm})$ for at least $1 \mathrm{~h}$ for acclimatization. Immediately after an intradermal injection of the pruritogen, they were put back into the same cells and their behaviors were videotaped for $1 \mathrm{~h}$ with personnel kept out of the observation room. The frequency of scratching around the injected site by the hind paw was counted by video playback. Since the mice rapidly and almost continuously scratched for about $1 \mathrm{~s}$, a series of these movements was counted as one bout of scratching with a hand-held counter (Line Seiki Co., Ltd., Tokyo, Japan) at 10-min intervals throughout the 60-min observation period. ${ }^{8}$

Data Processing Data were presented as means and S.E.M. Statistical significance was analyzed using Dunnett's multiple comparisons; $p<0.05$ was considered significant.

\section{RESULTS}

Effects of MEGL on Pruritogen-Induced Scratch- 
ing Since maximal or submaximal scratch-eliciting effects were observed after the intradermal injections of 5-HT (100 nmol/site), $\alpha$-methyl-5-HT $(100 \mathrm{nmol} / \mathrm{site}), \quad$ SLIGRL-NH ${ }_{2}$ (50 nmol/site), histamine $(100 \mathrm{nmol} / \mathrm{site})$, substance $\mathrm{P}$ (100 nmol/site), and compound 48/80 (10 $\mu \mathrm{g} / \mathrm{site}),{ }^{9-12)}$ these doses were used in the present study. In control mice which were given intradermal pruritogens after oral vehicle administration, the maximal scratching responses were observed during the initial 10-min period after the injection in all cases
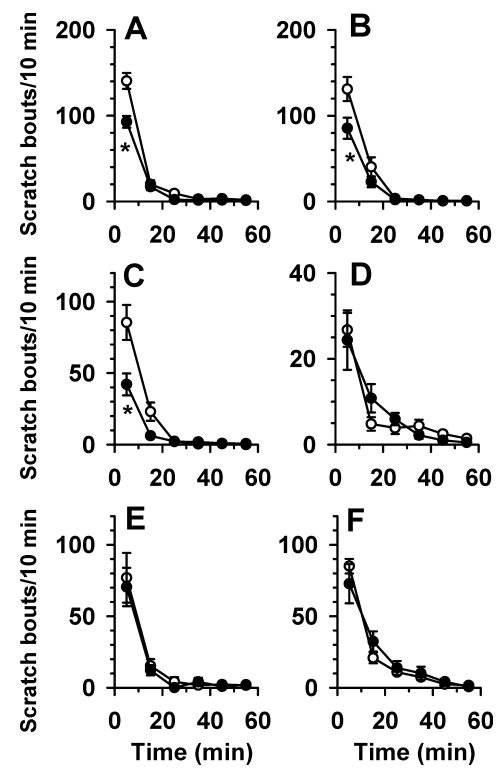

Fig. 1. Effects of Methanol Extract of Ganoderma lucidum (MEGL) on Pruritogen-Induced Scratching in Mice

Scratching was counted at 10-min intervals after intradermal injections of 5-hydroxytryptamine $(5-\mathrm{HT})(\mathrm{A}, 100 \mathrm{nmol} / \mathrm{site}), \alpha$-methyl-5-HT (B, $100 \mathrm{nmol} / \mathrm{site})$, SLIGRL$\mathrm{NH}_{2}(\mathrm{C}, 50 \mathrm{nmol} / \mathrm{site})$, histamine (D, $100 \mathrm{nmol} /$ site), substance $\mathrm{P}(\mathrm{E}, 100 \mathrm{nmol} / \mathrm{site})$, and compound 48/80 (F, $10 \mu \mathrm{g} / \mathrm{site}$ ). MEGL (A, 300 mg/kg; B-F, $1000 \mathrm{mg} / \mathrm{kg}$; closed circles) and vehicle (5\% gum arabic, open circles) were administered orally $1 \mathrm{~h}$ before the pruritogen injection. Values represent the means and S.E.M. for 8-24 animals. $* p<0.05$ when compared with vehicle (Student-Newman-Keuls test).
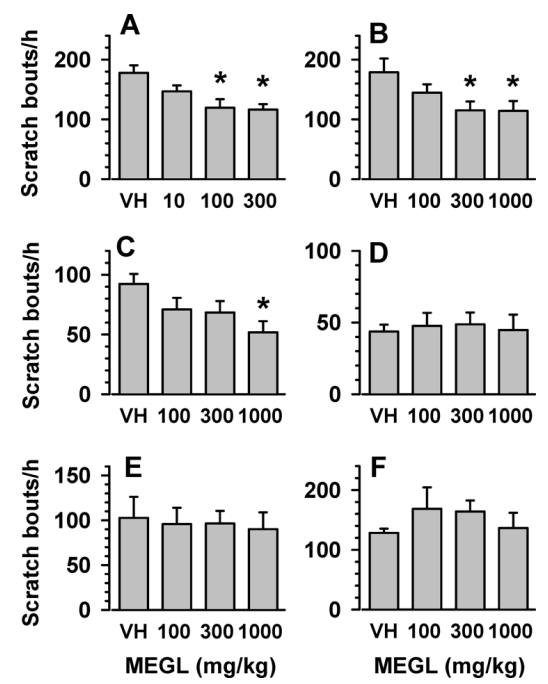

Fig. 2. Dose Dependency of Effects of Methanol Extract of Ganoderma lucidum (MEGL) on Pruritogen-Induced Scratching in Mice

5-Hydroxytryptamine (5-HT) (A, $100 \mathrm{nmol} / \mathrm{site}), \alpha$-methyl-5-HT (B, $100 \mathrm{nmol} / \mathrm{site}$ ), SLIGRL-NH $\mathrm{N}_{2}$ (C, $\left.50 \mathrm{nmol} / \mathrm{site}\right)$, histamine (D, $\left.100 \mathrm{nmol} / \mathrm{site}\right)$, substance $\mathrm{P}$ (E, $100 \mathrm{nmol} / \mathrm{site}$ ), and compound 48/80 (F, $10 \mu \mathrm{g} /$ site) were injected intradermally into the rostral back of the mouse. MEGL and a vehicle (VH: $5 \%$ gum arabic) were administered orally $1 \mathrm{~h}$ before the pruritogen injection. Values represent the means and S.E.M. for $8-24$ animals. $* p<0.05$, when compared with VH (Dunnett's multiple comparisons).
(Fig. 1). When MEGL (300 $\mathrm{mg} / \mathrm{kg}$ in the case of 5 -HT and $1000 \mathrm{mg} / \mathrm{kg}$ in the others) was administered orally $1 \mathrm{~h}$ before pruritogen injection, it inhibited scratching induced by 5-HT, $\alpha$-methyl-5-HT, and SLIGRL- $\mathrm{NH}_{2}$; inhibition was obvious during the initial 10-min period (Figs. 1A-C). MEGL $(1000 \mathrm{mg} / \mathrm{kg})$ did not affect scratching induced by histamine, substance $\mathrm{P}$, and compound 48/80 (Figs. 1D-F).

MEGL $(10-300 \mathrm{mg} / \mathrm{kg})$ produced a dose-dependent inhibition of 5-HT-induced scratching (Fig. 2A). Scratching induced by $\alpha$-methyl-5-HT was also attenuated by MEGL $(100-1000 \mathrm{mg} / \mathrm{kg}$ ) in a dose-dependent manner (Fig. 2B). MEGL (100- $1000 \mathrm{mg} / \mathrm{kg}$ ) produced a dose-dependent inhibition of scratching induced by SLIGRL-NH 2 (Fig. 2C). On the other hand, it $(100-1000 \mathrm{mg} / \mathrm{kg})$ did not suppress the scratching induced by histamine, substance $\mathrm{P}$, and compound 48/80 (Figs. 2D-F).

\section{DISCUSSION}

MEGL suppressed the scratching induced by intradermal SLIGRL-NH ${ }_{2}$, a PAR $_{2}$ receptor agonist, ${ }^{16)}$ and 5-HT in mice. The $\mathrm{PAR}_{2}$ receptor agonist tryptase has been suggested to be involved in pruritus of atopic dermatitis ${ }^{17,18)}$ and 5-HT is in pruritus of polycythemia vera. ${ }^{19)}$ Thus, it is interesting to examine the effects of MEGL on these $\mathrm{H}_{1}$ histamine-receptor antagonist-resistant pruritic diseases. Compound 48/80 can elicit scratching through mast cell-independent mechanism. ${ }^{20)}$ However, in ICR mice used here, compound 48/80induced scratching is suppressed by $\mathrm{H}_{1}$ histamine receptor antagonists $^{12,21)}$ and tryptase inhibitor, ${ }^{21)}$ suggesting the involvement of mast cell mediators in compound 48/80-induced scratching. With these findings taken into account, the result that MEGL did not inhibit scratching induced by compound 48/80 suggests that the mast cell is not the primary site of the antipruritic action of MEGL. Thus, the mechanism of antipruritic action of MEGL is different from those of chloroform extract and triterpene constituents (ganoderic acids) of $G$. lucidum, which have been shown to inhibit the release of histamine from mast cells. ${ }^{4,5)}$ It is intriguing to identify the constituent(s) responsible for the mast cellindependent antipruritic action of MEGL.

MEGL inhibited the scratching induced by the $\mathrm{PAR}_{2}$ receptor agonist SLIGRL-NH . $_{2} \mathrm{PR}_{2}$ receptor is expressed by epidermal keratinocytes in high densities. ${ }^{17,18)}$ MEGL did not inhibit scratching induced by substance $P$, although this peptide when injected intradermally acts on keratinocytes to release several itch mediators, ${ }^{22,23)}$ suggesting that MEGL does not inhibit epidermal keratinocytes. Therefore, keratinocytes may not be the main site of the inhibitory action of MEGL. $\mathrm{PAR}_{2}$ receptors are also expressed in primary sensory nerves ${ }^{17,24)}$ and $\mathrm{PAR}_{2}$ receptor agonist increases intracellular $\mathrm{Ca}^{2+}$ ions in primary cultures of dorsal root ganglion neurons. ${ }^{24)}$ Thus, the possible site of MEGL action is the primary afferents. $\mathrm{PAR}_{2}$ receptor agonist-induced scratching is not inhibited by $\mathrm{H}_{1}$ histamine receptor antagonist. ${ }^{11)}$ Capsaicin pretreatment inhibits itching induced by cowhage, probably its constituent protease mucunain, but not by histamine in humans, and in contrast, $\mathrm{H}_{1}$ receptor antagonist inhibits itching induced by histamine, but not by cowhage. ${ }^{25}$ ) Superficial dorsal horn neurons may receive itch signals. ${ }^{26,27)}$ The stimulation of $\mathrm{PAR}_{2}$ or histamine receptor in the skin 
causes Fos expression mainly in lamina I plus outer aspect of lamina II or inner aspect of lamina II, respectively, in mice. ${ }^{14)}$ Similarly, cowhage and histamine stimulation activates separate spinothalamic tract neurons in primates, ${ }^{28)}$ although one group reported that most superficial dorsal horn neurons were excited by both histamine and $\mathrm{PAR}_{2}$ receptor agonist. ${ }^{29)}$ These findings taken together suggest that different groups of primary afferents are responsible for itching induced by $\mathrm{PAR}_{2}$ receptor agonist and histamine. Thus, the present results that MEGL inhibited the scratching induced by $\mathrm{PAR}_{2}$ agonist but not by histamine raise the possibility that MEGL exerts inhibitory effect on $\mathrm{PAR}_{2}$-expressing primary afferents.

MEGL inhibited the scratching induced by intradermal 5HT and the 5- $\mathrm{HT}_{2}$ receptor agonist $\alpha$-methyl-5-HT. Scratching is induced by an intradermal injection of $\alpha$-methyl-5-HT, but not that of $5-\mathrm{HT}_{1}$ receptor and $5-\mathrm{HT}_{3}$ receptor agonists; in addition, scratching induced by $5-\mathrm{HT}$ is inhibited by 5 $\mathrm{HT}_{2}$ receptor antagonists, but not by $5-\mathrm{HT}_{3}$ antagonists. ${ }^{10)}$ There are three $5-\mathrm{HT}_{2}$ receptor subtypes $-5-\mathrm{HT}_{2 \mathrm{~A}}, 5-\mathrm{HT}_{2 \mathrm{~B}}$ and $5-\mathrm{HT}_{2 \mathrm{C}}$ receptors. ${ }^{30}$ ) The expression of $5-\mathrm{HT}_{2 \mathrm{~A}}$, but not $5-\mathrm{HT}_{2 \mathrm{~B}}$, receptor mRNA has been detected in murine dorsal root ganglia and skin (Yamaguchi and Kuraishi, unpublished observation). The expression level of $5-\mathrm{HT}_{2 \mathrm{~A}}$ mRNA was higher in the ganglia than in the skin. Immunohistochemical analysis showed that $5-\mathrm{HT}_{2 \mathrm{~A}}$ receptor-expressing cells are not present in healthy skin. ${ }^{31)} 5-\mathrm{HT}_{2 \mathrm{C}}$ receptor mRNA was detected in the skin, but the expression level was low. Taken together, the present results suggest that MEGL acts on the $5-\mathrm{HT}_{2 \mathrm{~A}}$ receptor-expressing primary afferents to inhibit scratching.

Superficial dorsal horn neurons respond to intradermal injections of SLIGRL-NH $\mathrm{N}_{2}$ and 5-HT; 70\% of $\mathrm{PAR}_{2}$ agonistresponding neurons respond to 5 -HT and $80 \%$ of 5 -HT-responding neurons respond to $\mathrm{PAR}_{2}$ agonist. ${ }^{32)} \mathrm{PAR}_{2}$ agonist and 5-HT cause Fos expression in the overlapping area of the superficial dorsal horn. ${ }^{33)}$ In our preliminary experiments, $\mathrm{PAR}_{2}$ receptor and $5-\mathrm{HT}_{2 \mathrm{~A}}$ receptors were found to be in the same dorsal root ganglion neurons. Taken together, it is suggested that common primary afferents mediate itch signals elicited by the stimulation of 5-HT and $\mathrm{PAR}_{2}$ receptors in the skin. Therefore, the present results that MEGL inhibited the scratching induced by SLIGRL- $\mathrm{NH}_{2}$ and 5-HT raise the possibility that primary afferents expressing $\mathrm{PAR}_{2}$ and $5-\mathrm{HT}_{2 \mathrm{~A}}$ receptors are the sites of MEGL action.

Acknowledgments This study was supported in part by a Grant-in-Aid for Scientific Research [(B) \#19390020] and by a Grant-in-Aid for Young Scientists [(B) \#19790051] from the Japan Society for the Promotion Sciences.

\section{REFERENCES}

1) Wahlgren C. F., Acta Derm. Venereol. Suppl., 165, 1-53 (1991).

2) Min B. S., Gao J. J., Nakamura N., Hattori M., Chem. Pharm. Bull.,
48, 1026-1033 (2000)

3) Kimura Y., Taniguchi M., Baba K., Anticancer Res., 22, 3309-3318 (2002).

4) Kohda H., Tokumoto W., Sakamoto K., Fujii M., Hirai Y., Yamasaki K., Komoda Y., Nakamura H., Ishihara S., Uchida M., Chem. Pharm. Bull., 33, 1367-1374 (1985).

5) Tasaka K., Akagi M., Miyoshi K., Mio M., Makino T., Agents Actions, 23, 153-156 (1988).

6) Sugimoto Y., Umakoshi K., Nojiri N., Kamei C., Eur. J. Pharmacol., 351, 1-5 (1998).

7) Andoh T., Nishikawa Y., Yamaguchi-Miyamoto T., Nojima H., Narumiya S., Kuraishi Y., J. Invest. Dermatol., 127, 2042-2047 (2007).

8) Kuraishi Y., Nagasawa T., Hayashi K., Satoh M., Eur. J. Pharmacol., 275, 229-233 (1995).

9) Andoh T., Nagasawa T., Satoh M., Kuraishi Y., J. Pharmacol. Exp. Ther, 286, 1140-1145 (1998).

10) Yamaguchi T., Nagasawa T., Satoh M., Kuraishi Y., Neurosci. Res., 35, $77-83$ (1999).

11) Tsujii K., Andoh T., Lee J. B., Kuraishi Y., J. Pharmacol. Sci., 108, $385-388$ (2008).

12) Inagaki N., Nakamura N., Nagao M., Musoh K., Kawasaki H., Nagai H., Eur. J. Pharmacol., 367, 361-171 (1999).

13) Maekawa T., Nojima H., Kuraishi Y., Jpn. J. Pharmacol., 84, 462466 (2000).

14) Nakano T., Andoh T., Lee J. B., Kuraishi Y., Neuroreport, 19, 723726 (2008).

15) Nakano T., Andoh T., Sasaki A., Nojima H., Kuraishi Y., Acta Derm. Venereol., 88, 449-454 (2008).

16) Nystedt S., Emilsson K., Wahlestedt C., Sundelin J., Proc. Natl. Acad. Sci. U.S.A., 91, 9208-9212 (1994).

17) Steinhoff M., Neisius U., Ikoma A., Fartasch M., Heyer G., Skov P. S., Luger T. A., Schmelz M., J. Neurosci., 23, 6176-6180 (2003).

18) Tsujii K., Andoh T., Ui H., Lee J. B., Kuraishi Y., J. Pharmacol. Sci., 109, 388-395 (2009).

19) Fjellner B., Hägermark O., Acta Derm. Venereol., 59, 505-512 (1979).

20) Inagaki N., Igeta K., Kim J. F., Nagao M., Shiraishi N., Nakamura N., Nagai H., Eur. J. Pharmacol., 448, 175-183 (2002).

21) Ui H., Andoh T., Lee J. B., Nojima H., Kuraishi Y., Eur. J. Pharmacol., 530, 172-178 (2006).

22) Andoh T., Katsube N., Maruyama M., Kuraishi Y., J. Invest. Dermatol., 117, 1621-1626 (2001).

23) Andoh T., Kuraishi Y., Br. J. Pharmacol., 138, 202-208 (2003).

24) Steinhoff M., Vergnolle N., Young S. H., Tognetto M., Amadesi S., Ennes H. S., Trevisani M., Hollenberg M. D., Wallace J. L., Caughey G. H., Mitchell S. E., Williams L. M., Geppetti P., Mayer E. A., Bunnett N. W., Nat. Med., 6, 151-158 (2000).

25) Johanek L. M., Meyer R. A., Hartke T., Hobelmann J. G., Maine D. N., LaMotte R. H., Ringkamp M., J. Neurosci., 27, 7490-7497 (2007).

26) Andrew D., Craig A. D., Nat. Neurosci., 4, 72-77 (2001).

27) Omori Y., Andoh T., Shirakawa H., Ishida H., Hachiga T., Kuraishi Y., Neuroreport, 20, 478-481 (2009).

28) Davidson S., Zhang X., Yoon C. H., Khasabov S. G., Simone D. A., Giesler G. J. Jr., J. Neurosci., 27, 10007-10014 (2007).

29) Akiyama T., Carstens M. I., Carstens E., J. Neurophysiol., 102, 2176 2183 (2009).

30) Roth B. L., Willins D. L., Kristiansen K., Kroeze W. K., Pharmacol. Ther., 79, 231-257 (1998).

31) Nordlind K., Thorslund K., Lonne-Rahm S., Mohabbati S., Berki T., Morales M., Azmitia E. C., Arch. Dermatol. Res., 298, 99-106 (2006).

32) Akiyama T., Merrill A. W., Carstens M. I., Carstens E., J. Neurosci., 29, 6691-6699 (2009).

33) Akiyama T., Merrill A. W., Zanotto K., Carstens M. I., Carstens E., J. Pharmcol. Exp. Ther, 329, 945-951 (2009). 